\title{
Involvement of Histaminergic System in the Anxiolytic-Like Activities of Morus alba Leaves in Mice
}

\author{
Seungheon Lee, ${ }^{a}$ Dong Hyun Kim, ${ }^{b}$ Ji Hye Lee, ${ }^{e}$ Eun Seong Ko, ${ }^{a}$ Won Bo Oh, ${ }^{a}$ Yong Taek Seo, ${ }^{c}$ \\ Young Pyo Jang, ${ }^{c, d}$ Jong Hoon Ryu, ${ }^{c, d}$ and Ji Wook Jung*,e \\ ${ }^{a}$ Department of Aquatic Biomedical Sciences, School of Marine Biomedical Sciences, College of Ocean Science, Jeju \\ National University; Jeju 690-756, Republic of Korea: ${ }^{b}$ School of Clinical Sciences, University of Bristol; Dorothy \\ Hodgkin building, Whiston Street, Bristol, BS1 3NY, United Kingdom: ${ }^{c}$ Department of Oriental Pharmaceutical \\ Science, College of Pharmacy, Kyung Hee University; ${ }^{d}$ Kyung Hee East-West Pharmaceutical Research Institute, \\ College of Pharmacy, Kyung Hee University; Hoeki-dong, Dongdaemoon-Ku, Seoul 130-701, Republic of Korea: and \\ ${ }^{e}$ Department of Herbal Medicinal Pharmacology, College of Herbal Bio-industry, Daegu Haany University; Yugok- \\ dong, Gyeongsan 712-715, Republic of Korea. \\ Received February 9, 2013; accepted July 31, 2013; advance publication released online August 22, 2013
}

The aim of this study was to identify the effects of $85 \%$ methanolic extract of Morus alba leaves (EMA), which is a traditional herb, in mice. The effects of EMA on the anxiolytic-like behaviour were studied using the elevated plus maze (EPM) and hole-board test. To elucidate the mode of action of the anxiolytic-like effects of EMA, the mice were subjected to the co-administration of EMA $(200 \mathrm{mg} / \mathrm{kg}$, per os (p.o.)) and either antagonist. EMA (at 200 or $400 \mathrm{mg} / \mathrm{kg}$ ) significantly increased the percentages of time-spent in the open arms and entries into the open arms of the EPM versus vehicle-treated control group $(p<0.05)$. Moreover, in the hole-board test, EMA $(200$ and $400 \mathrm{mg} / \mathrm{kg})$ significantly increased the number of head-dips versus vehicle-treated control group $(\boldsymbol{p}<\mathbf{0 . 0 5})$. However, there were no changes in the locomotor activity and myorelaxant effects in any group compared with the vehicle-treated control group. In addition, the anxiolytic-like effects of EMA were abolished by thioperamide $\left(10 \mathrm{mg} / \mathrm{kg}\right.$, intraperitoneally (i.p.)), which is a histamine $\mathrm{H}_{3}$ receptor antagonist. Moreover, results from reverse transcription polymerase chain reaction (RT-PCR) also revealed that the amygdalal histidine decarboxylase mRNA expression levels in EMA $(200 \mathrm{mg} / \mathrm{kg})$-treated group were significantly higher than those in the vehicle-treated controls $(p<0.05)$. These results suggest that EMA might prove to be an effective anxiolytic agent and that EMA acts via the histaminergic system in central nerve system.

Key words anxiety; Morus alba; elevated plus-maze; histamine; thioperamide

Mulberry tree (Morus alba L., Moraceae) is cultivated in China, Japan and Korea and is an important herbal material in traditional Chinese medicine. For example, the root bark of mulberry trees has long been used for anti-inflammatory, diuretic, antitussive, and antipyretic purposes in Oriental medicine. ${ }^{1)}$ Moreover, fruit extract of M. alba was reported to modulate the monoamine oxidase activity during exercise and to promote the capability of physical activities. ${ }^{2}$ In addition to those herbal materials from $M$. alba, the leaves of this plant are one of the well-known traditional Chinese medicinal herbs and have been traditionally used to cure or prevent diabetic hyperglycemia. ${ }^{3,4)}$ Based on those traditional usages, researchers reported that nitric oxide synthase positive neurons were decreased by the treatment with $M$. alba extracts in the various hypothalamic areas in the streptozotocin-induced diabetic rat brain. ${ }^{4)}$ Interestingly, those hypothalamic areas, including the paraventricular nucleus and ventromedial hypothalamic nucleus are rich in histaminergic neurons originating from the tuberomammillary body. ${ }^{5)}$ These findings suggest a possibility that the leaves of $M$. alba may affect the activity of the histaminergic nervous system. Moreover, several clinically useful anxiolytics have been found to affect the turnover rate of brain histamine in the rat brain. For example, diazepam inhibits histamine turnover by acting on $\gamma$-aminobutyric acid $(\mathrm{GABA})_{\mathrm{A}}$ receptors $^{6)}$ and also inhibits histamine release in the rat striatum. ${ }^{7}$ Although earlier report has suggested that

The authors declare no conflict of interest. methanolic extract of $M$. alba L. has anxiolytic effects mediated through the $\mathrm{GABA}_{\mathrm{A}}$-benzodiazepine mechanism, ${ }^{8)}$ there was no evidence to prove it. Furthermore, there have been no pharmacological studies upon of the effects of leaves of $M$. alba on the histaminergic system.

Therefore, we hypothesize that the leaves of M. alba administered in vivo may affect histaminergic transmission directly or indirectly in the brain and may result in anxiogenic or anxiolytic-like behaviours. If the leaves of $M$. alba act as an agonist of the histamine $\mathrm{H}_{1}$ receptor or an antagonist of histamine $\mathrm{H}_{2}$ or $\mathrm{H}_{3}$ receptors, anxiety-like behaviours will be observed. ${ }^{9)}$ To test this hypothesis, elevated plus-maze (EPM) and hole-board tests were employed to investigate whether the leaves of $M$. alba specifically targets histaminergic systems in the mouse brain.

\section{MATERIALS AND METHODS}

Materials Quercetin, thioperamide, WAY-100635, and flumazenil were obtained from Sigma-Aldrich (St. Louis, MO, U.S.A.). M. alba leaves were obtained from a herbalist supplier in Seoul, Korea, and voucher specimens (DHUHMP-09-04) were maintained. Diazepam was supplied by the local pharmaceutical company (Daewon Pharm. Co., Ltd.). The material was authenticated by Prof. Yong Han Kim of Department of Herbal Medicinal Pharmacology, College of Herbal Bio-industry, Daegu Haany University. All other materials were of the highest grade and were obtained from standard commercial 
sources.

Animals Male ICR mice at 5 weeks of age, weighing 23-25 g, were purchased from the Orient Co. (a branch of Charles River Laboratories, Seoul) and housed in the University Animal Care Unit for 1 week prior to experimentation. The animals were housed 5 per cage, allowed free access to water and food, and maintained under constant temperature $\left(23 \pm 1^{\circ} \mathrm{C}\right)$, humidity $(60 \pm 10 \%)$ and a 12 -h light/ dark cycle (lights on from 07:00-19:00h). Animal treatment and maintenance were conducted in accordance with the Principles of Laboratory Animal Care (NIH Publication No. 85-23, revised 1985) and with the Animal Care and Use Guidelines of Daegu Haany University, Korea.

Sample Preparation A methanolic extract of the M. alba leaves (EMA) was prepared with $85 \%$ methanolic solution under a sonicator $\left(25^{\circ} \mathrm{C}\right)$ for $1 \mathrm{~h}$. Then, the extract solution obtained was filtered using a Whatman No. 1 filter paper and was concentrated on a water bath under vacuo. It was then, frozen and lyophilised (Eyela, model FDU-2000, Japan) to yield methanolic extracts (yield 3.4\%), which were then stored at $-20^{\circ} \mathrm{C}$ until required.

Ultra Performance (UP) LC Quantitative Analysis Reverse-phase UPLC was performed on the Waters Acquity UPLC H class (Milford, Massachusetts, U.S.A.), consisting of a Quarternary Solvent Manager pump, Sample Manager-TN and PDA detector. Empower 3 pro software (Milford, Massachusetts, U.S.A.) was used for UPLC data analysis. Chromatographic separation was accomplished on a Waters $\mathrm{C} 18$ reverse phase column (Acquity BEH $50 \times 1.0 \mathrm{~mm}$ i.d., $1.7 \mu \mathrm{m}$ ) at $30^{\circ} \mathrm{C}$ and monitored at $350 \mathrm{~nm}$. A gradient solvent system consisted of methanol (solvent A) and water (solvent B) was used from 5\% (solvent A): $95 \%$ (solvent $\mathrm{B}$ ) to $100 \%$ (solvent $\mathrm{A}$ ): $0 \%$ (solvent B) for $20 \mathrm{~min}$ at a flow rate of $0.5 \mathrm{~mL} / \mathrm{min}$. The standard stock solutions were prepared by dissolving standards in $100 \%$ methanol to set a final concentration of $10 \mathrm{mg} / \mathrm{mL}$. After ultracentrifugation at $9000 \mathrm{rpm}$ and filtration through a syringe filter $(0.45 \mu \mathrm{m}$, Pall Co. $), 2 \mu \mathrm{L}$ of sample was injected 6 times. The average retention time of quercetin was $9.3 \mathrm{~min}$. The calibration curve of quercetin was drawn with $\left(R^{2}\right)$ of quercetin was as follows: $y=48143 x-23093 ; R^{2}=0.999935$ in standard concentrations ranging from 1 to $500 \mu \mathrm{g} / \mathrm{mL}$. Using these equations, the quantity of quercetin in the EMA was calculated and determined as $14.80 \pm 0.48 \mu \mathrm{g} / \mathrm{g}$.

EPM Test The EPM for mice consisted of two perpendicular open arms $(30 \times 7 \mathrm{~cm})$ and two enclosed arms $(30 \times 7 \mathrm{~cm})$ with $20 \mathrm{~cm}$ high walls, extending from the central platform $(7 \times 7 \mathrm{~cm})$. The open and closed arms were connected by a central square $(7 \times 7 \mathrm{~cm})$, to give an apparatus of a plus sign in the shape of a plus sign. The floor and walls of the maze were constructed from the dark opaque polyvinyl plastic. The maze was raised to a height of $50 \mathrm{~cm}$ above the floor level in a dimly illuminated room (20 Lux) and a video camera was suspended above the maze to record the movements for analysis. ${ }^{10,11)}$ Each mouse was placed at the centre of the platform, its head facing an open arm. The animals were tested individually and only for $5 \mathrm{~min}$. The maze was cleaned after each trial to remove any residue or odours. The following measurements were taken and analysed using the video-based Ethovision System: the number of entries into the open or closed arms, the time spent in each arm, and the total distance moved in the EPM. All of the experiments were performed between
$10: 00$ and $16: 00$.

One hour after the EMA treatment (50, 100, 200 and $400 \mathrm{mg} / \mathrm{kg}$, per os (p.o.)), the mice were placed in the EPM. EMA was suspended in a $10 \%$ Tween 80 solution (v/v). The mice in the control group were given the vehicle solvent only, and the animals were tested individually for $5 \mathrm{~min}$. In a pilot study, we observed that EMA exhibited anxiolytic-like activity $1 \mathrm{~h}$ after oral administration and diazepam exhibited similar activity $30 \mathrm{~min}$ after intraperitoneal administration. Therefore, we selected these time points for the present study. The doses of EMA employed in the present study were based on the traditional dosage $(5-9 \mathrm{~g}){ }^{12)}$ In a separate antagonism study, the mice were subjected to the co-administration of EMA $(200 \mathrm{mg} / \mathrm{kg}$, p.o.) and either WAY-100635 (0.3 mg/kg, intraperitoneally (i.p.)), ${ }^{13)}$ flumazenil $(10 \mathrm{mg} / \mathrm{kg}$, i.p. $),{ }^{14)}$ or thioperamide $(10 \mathrm{mg} / \mathrm{kg})^{15)} 1 \mathrm{~h}$ and $30 \mathrm{~min}$ prior to testing. The mice were treated with diazepam $(1 \mathrm{mg} / \mathrm{kg}$, i.p.) $30 \mathrm{~min}$ before EPM test and used as the positive controls.

Hole-Board Test The hole-board apparatus (Ugo Basile, Italy) consisted of gray Perspex panels $(40 \times 40 \mathrm{~cm}, 2.2 \mathrm{~cm}$ thick) with 16 equidistant holes $3 \mathrm{~cm}$ in diameter in the floor. Photocells below the surface of the holes measured the number of head-dips. The board was positioned $15 \mathrm{~cm}$ above the table. The method was adapted from. ${ }^{16)}$ Mice were transported to the dimly lit laboratory at least $1 \mathrm{~h}$ before testing. Each animal was individually placed alone in the centre of the board facing away from the observer and its behaviour was recorded for $5 \mathrm{~min}$, including the number of head-dips was recorded. Mice were orally administered EMA (50, 100, 200 and $400 \mathrm{mg} / \mathrm{kg}$ ) $1 \mathrm{~h}$ prior to the testing.

Horizontal Wire Test Immediately after the EPM test in the single treatment of EMA, a horizontal wire test was carried out by treating the mice with EMA (50, 100, 200 and $400 \mathrm{mg} / \mathrm{kg}$, p.o.) according to a slightly modified version of the method reported by Bonetti et al. ${ }^{17)}$ Briefly, the mice were lifted by the tail and allowed to grasp a horizontally strung wire $(1 \mathrm{~mm}$ diameter, $15 \mathrm{~cm}$ length, and placed $20 \mathrm{~cm}$ above the table) with their forepaws, after which they were released. The number of mice from each treatment group that did not grasp the wire with their forepaws or actively grasped the wire with at least one hind paw within a $10 \mathrm{~s}$ period was recorded. A myorelaxant drug would impair the ability of the mice to grasp the wire, and muscle relaxation is commonly associated with sedation.

Locomotor Activity in the Open Field Test Testing was conducted in clear black Plexiglas boxes $(40 \times 40 \times 40 \mathrm{~cm})$ equipped with the video-based Ethovision System (Noldus, Wageningen, the Netherlands). The mice were placed in the centre of the apparatus to evaluate horizontal locomotor activity $1 \mathrm{~h}$ after being treated with EMA (50, 100, 200 and $400 \mathrm{mg} / \mathrm{kg}$ ); the mice were and video-recorded for $5 \mathrm{~min}$. Horizontal locomotor activity was expressed as total ambulatory distance and the frequency of rearing. ${ }^{18)}$

Reverse Transcription Polymerase Chain Reaction (RTPCR) For RT-PCR, the mice not subjected to behavioral tests were sacrificed and the amygdala was rapidly dissected on an ice-cold glass plate $1 \mathrm{~h}$ or $30 \mathrm{~min}$ after the final administration of EMA to detect the levels of expressed histidine decarboxylase (HDC) mRNA. Isolated mice amygdala were homogenized in $1 \mathrm{~mL}$ Trizol Reagent (Molecular Research Center, OH, U.S.A.) and incubated in the same solution for 


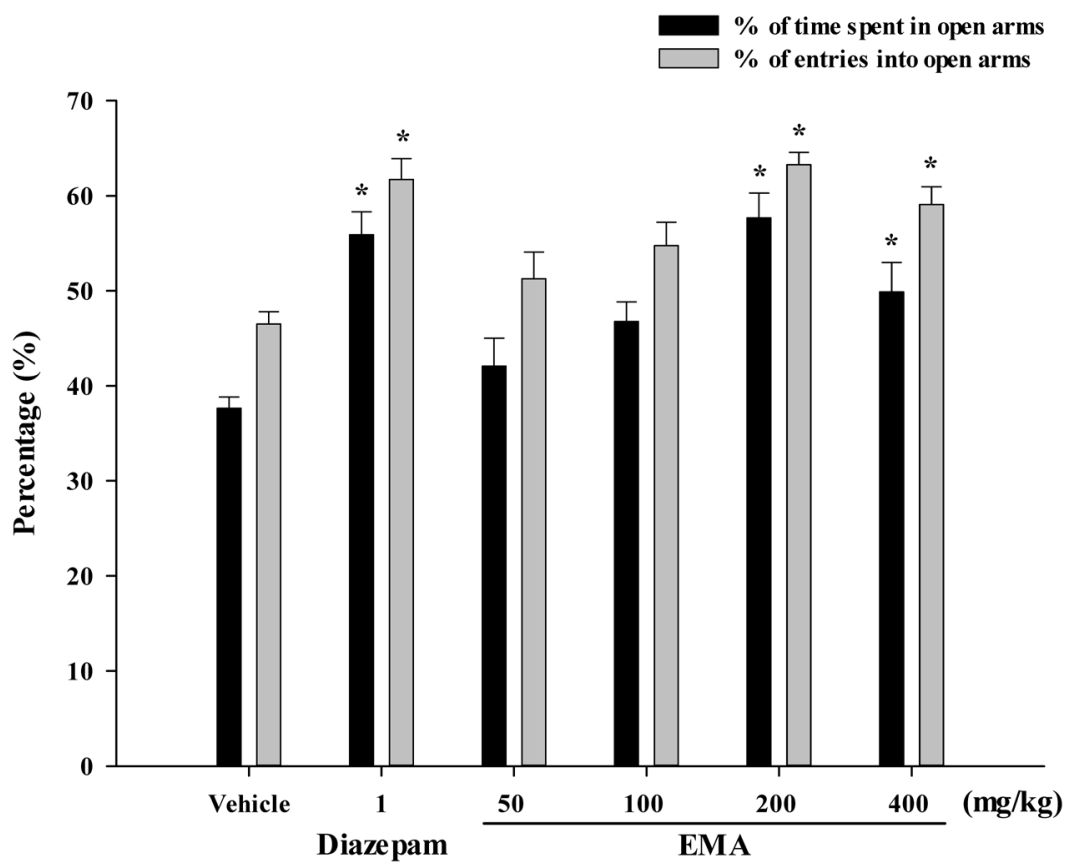

Fig. 1. Effect of Treatment of the $80 \%$ Methanolic Extract of M. alba Leaves (EMA) on the Percentages of the Time Spent in and the Number of Entries into the Open Arms of the Elevated Plus-Maze over a $5 \mathrm{~min}$ Test Period in the Mice

Mice were administered EMA $(50,100,200$ or $400 \mathrm{mg} / \mathrm{kg}$, p.o.). Each bar represents the mean \pm S.E.M. of 10 mice. $p$ values for the group comparisons were obtained by one way ANOVA followed by Student-Newman-Keuls test $\left({ }^{*} p<0.05\right.$ compared with the vehicle-treated control group).

5 min at RT and then stored at $-70^{\circ} \mathrm{C}$ until used. For RNA extraction, $0.2 \mathrm{~mL}$ of chloroform was added per $\mathrm{ml}$ of extract and the samples were further incubated for $3 \mathrm{~min}$ at RT. They were then centrifuged at $15000 \times \boldsymbol{g}$ for $15 \mathrm{~min}$ and the supernatant was incubated with isopropyl alcohol $(0.5 \mathrm{~mL} / \mathrm{mL})$ at RT for $10 \mathrm{~min}$. Samples were then centrifuged at $15000 \times \mathbf{g}$ for $15 \mathrm{~min}$ at RT and the RNA pellet was washed once with $85 \%$ ethanol. RNA was redissolved in $10 \mu \mathrm{L}$ RNase-free water and stored at $-70^{\circ} \mathrm{C}$ until used. To remove any residual contaminating DNA, RNA was incubated with $1 \mu \mathrm{L}$ DNAse (RQDNAse, Promega, Alexandria, New South Wales, Australia) at $37^{\circ} \mathrm{C}$ for $30 \mathrm{~min}$, after which $90 \mu \mathrm{L}$ of RNase-free water was added and the RNA was extracted a second time with Trizol Reagent and chloroform as described above. The final RNA pellet was dissolved in $10 \mu \mathrm{L}$ RNase-free water.

Amygdalal RNA $(1 \mu \mathrm{L})$, isolated as described above, was mixed with an equal volume of oligo-dT $(50 \mu \mathrm{M})$ and deoxyribonucleotide triphosphates (10 mm; dNTP) and $7 \mu \mathrm{L}$ of RNasefree water, then denatured by incubation for $5 \mathrm{~min}$ at $65^{\circ} \mathrm{C}$. This mix was then placed on ice for $1 \mathrm{~min}$. For the synthesis of amygdalal cDNA by reverse transcription, DiaStar ${ }^{\mathrm{TM}}$ RT Kit (SolGent, Korea) were added and the mix was incubated at $50^{\circ} \mathrm{C}$ for $60 \mathrm{~min}$, then at $85^{\circ} \mathrm{C}$ for $5 \mathrm{~min}$ to inactivate the reverse transcriptase. Samples were cooled on ice, incubated with $1 \mu \mathrm{L}$ RNase (SolGent, Korea) at $37^{\circ} \mathrm{C}$ for $20 \mathrm{~min}$ to digest the template RNA.

The amygdalal cDNA was amplified by PCR using synthetic specific primers to HDC, glyceraldehyde-3-phosphate dehydrogenase (GAPDH) as follows :

HDC

$$
\begin{aligned}
& \text { 5'-GAT CAG ATT TCT ACC TGT GG-3' (sense) } \\
& \text { 5'-GTG TAC CAT CAT CCA CTT GG-3' (antisense) } \\
& \text { 5APDH } \\
& \text { 5'-GCC AAG GTC ATC CAT GAC AAC-3' (sense) }
\end{aligned}
$$$$
\text { GAPDH }
$$

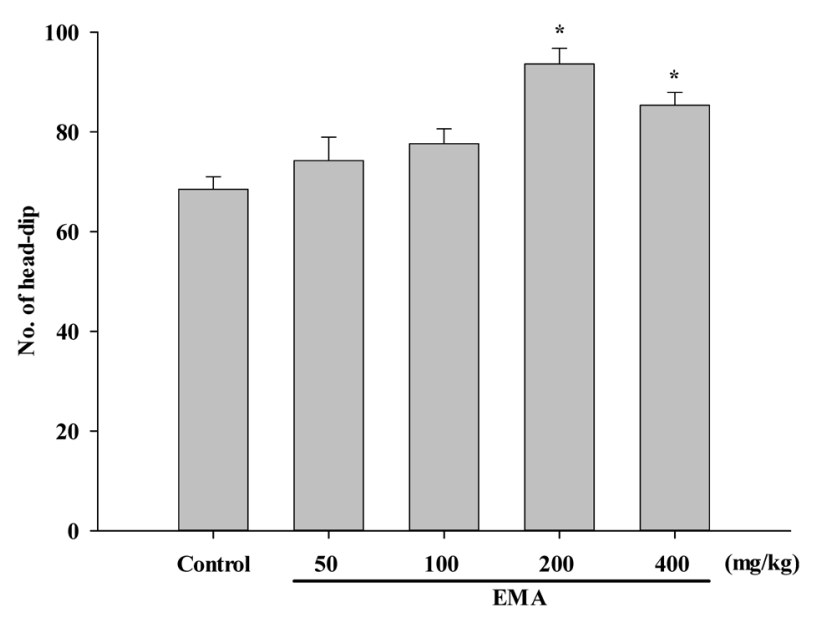

Fig. 2. Effects of $M$. alba Leaves (EMA) on the Changes in Headdipping Behaviours in Mice Tested on the Hole-Board

Mice were administered EMA $(50,100,200$ or $400 \mathrm{mg} / \mathrm{kg}$, p.o. $)$. Each bar represents the mean \pm S.E.M. of 10 mice. $p$ values for group comparisons were obtained by one way ANOVA followed by Student-Newman-Keuls test $\left({ }^{*} p<0.05\right.$ versus the vehicle-treated control).

\section{5'-AGT GTA GCC CAG GAT GCC CTT-3' (antisense).}

In separate reactions, specific primers $(1 \mu \mathrm{L}$ of $10 \mu \mathrm{M})$ were added to $5 \mu \mathrm{L}$ of cDNA, in a final volume of $50 \mu \mathrm{L}$ PCR reaction mix ( $2 \mathrm{~mm} \mathrm{dNTP;} 2 \mathrm{~mm} \mathrm{MgCl}_{2} ; 1 \mathrm{U}$ TaqDNA Polymerase). Amplification was initiated by denaturation for $5 \mathrm{~min}$ at $95^{\circ} \mathrm{C}$ and then annealing of 40 cycle for $40 \mathrm{~s}$ at $57^{\circ} \mathrm{C}$, and subsequent elongation for $60 \mathrm{~s}$ at $72^{\circ} \mathrm{C}$ The amplified PCR products were analyzed by $1 \%$ agarose gel electrophoresis in Trisacetate-ethylenediaminetetraacetic acid (EDTA) (TAE) buffer and stained with EcoDyeTM DNA staining solution (SolGent, Korea). The agarose gels were examined under UV light using a gel documentation system (DAIHAN Scientific, Korea). 


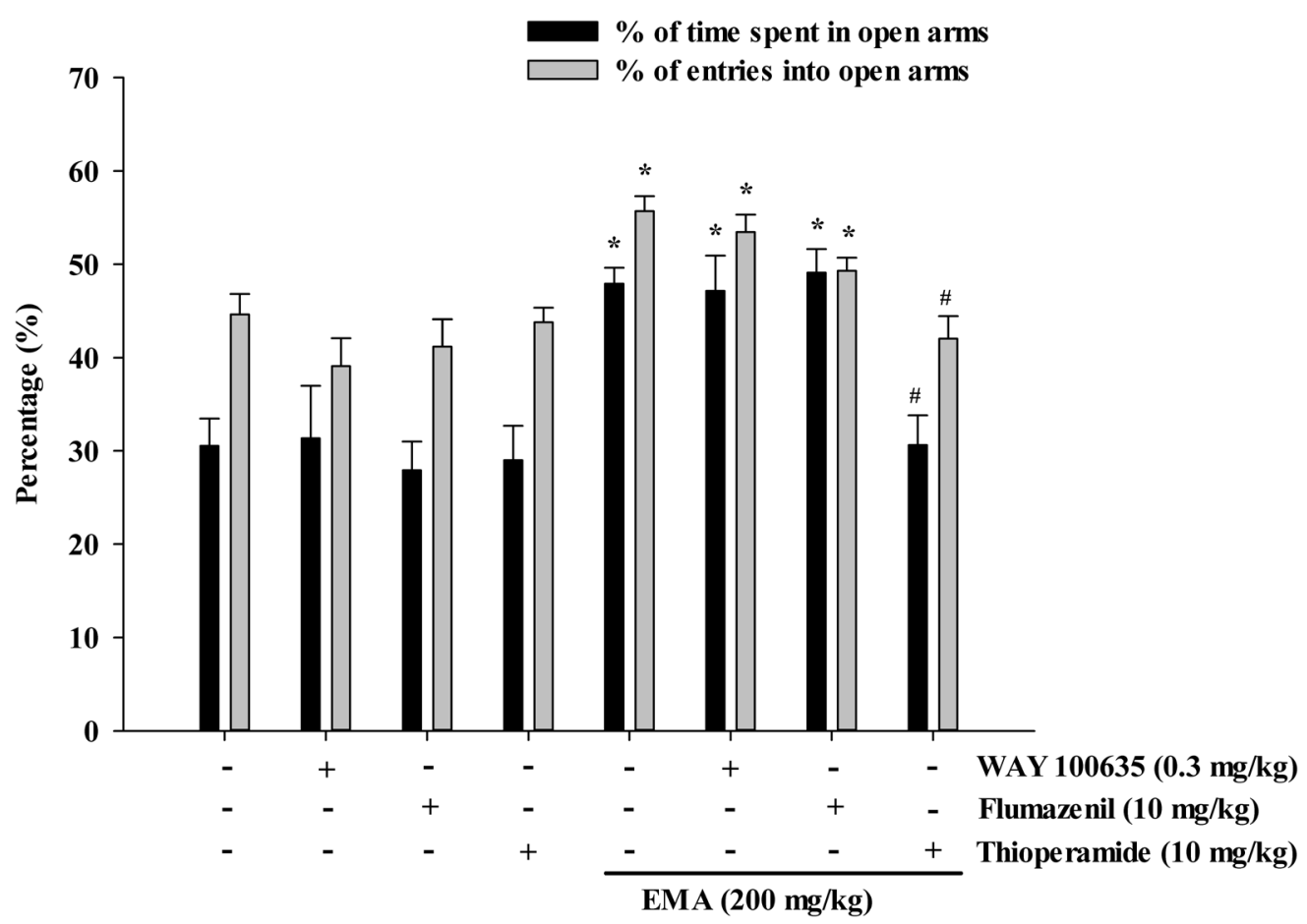

Fig. 3. Anxiolytic-Like Effects of M. alba Leaves (EMA) Were Blocked by Thioperamide but Not by WAY 100635 or Flumazenil

The data are expressed as the mean ( \pm S.E.M.) of the percentage of the time spent in and the number of entries into the open arms of the elevated plus-maze, $1 \mathrm{~h}$ after the oral administration of EMA $(200 \mathrm{mg} / \mathrm{kg})$, EMA $(200 \mathrm{mg} / \mathrm{kg})+$ WAY $100635(0.3 \mathrm{mg} / \mathrm{kg})$, flumazenil $(10 \mathrm{mg} / \mathrm{kg})$, or thioperamide $(10 \mathrm{mg} / \mathrm{kg})(30 \mathrm{~min}$ prior testing, i.p.), or saline; $n=10$ mice per group. $p$ values for the group comparisons were obtained by two way ANOVA followed by Student-Newman-Keuls test $(* p<0.05$ versus the vehicle-treated control, ${ }^{\#} p<0.05$ compared with the EMA-administered group).

GAPDH was used to as an internal loading control.

Statistical Analysis Values are expressed as the mean \pm S.E.M. Data were analysed by a one-way analysis of variance (ANOVA) followed by the Student-Newman-Keuls test for multiple comparisons. For the antagonism study, the interactions between the agonist and antagonist were analysed separately with a two-way ANOVA [factors: agonist versus antagonist]; pairwise comparisons for the assessment of the antagonist influence on the agonist effects were conducted by using Tukey's test. Statistical significance was set at $p<0.05$.

\section{RESULTS}

Effects of EMA Treatment in the EPM The percentages of time spent in the open arms were significantly increased in the EMA-treated mice (200 or $400 \mathrm{mg} / \mathrm{kg}$ ) compared with vehicle-treated group $(57.7 \pm 2.6 \%$ or $49.9 \pm 3.1 \%$, respectively, versus $37.6 \pm 1.2 \%$, Fig. $1 ; p<0.05)$. Also, the percentages of numbers of entries into open arms were significantly increased in the EMA-treated mice (200 or $400 \mathrm{mg} / \mathrm{kg}$ ) compared with vehicle-treated group $(63.3 \pm 1.3 \%$ or $59.1 \pm 1.9 \%$, respectively, versus $46.5 \pm 1.3 \%$, Fig. $1 ; p<0.05)$. However, no significant change was observed in terms of the percentages of time spent in open arms and number of entries into open arms at 50 and $100 \mathrm{mg} / \mathrm{kg}$ of EMA. In the diazepam-treated $(1 \mathrm{mg} / \mathrm{kg})$ group, which was a positive control, the percentages of time spent in open arms and number of entries into the open arms were significantly increased compared with the saline-treated group $(55.9 \pm 2.4 \%$ and $61.7 \pm 2.2 \%, p<0.05)$. Thereafter, we adopted $200 \mathrm{mg} / \mathrm{kg}$ dosing for further studies.

Effects of EMA Treatment in Hole-Board Test The effects of EMA on the changes in head-dipping behaviour in mice are shown in Fig. 2. EMA-treated mice manifested significant increases in the number of head-dips at doses of 200 and $400 \mathrm{mg} / \mathrm{kg}(93.6 \pm 3.2$ or $85.4 \pm 2.6$, respectively, versus $68.5 \pm 2.5$, Fig. $2 ; p<0.05)$. However, there were no significant increases at doses of 50 and $100 \mathrm{mg} / \mathrm{kg}$ of EMA.

Effects of WAY-100635, Flumazenil and Thioperamide, on the Anxiolytic-Like Activity of EMA To determine which nervous system is involved in the anxiolytic effect of EMA, the EMA $(200 \mathrm{mg} / \mathrm{kg})$ treated mice were subjected to a co-treatment with either WAY-100635, which is a $5-\mathrm{HT}_{1 \mathrm{~A}}$ receptor antagonist, or flumazenil, which is a $\mathrm{GABA}_{\mathrm{A}}$ receptor antagonist. As shown in Fig. 3, the anxiolytic-like effects of EMA were not antagonised either by WAY-100635 $(0.3 \mathrm{mg} / \mathrm{kg})$ or flumazenil $(10 \mathrm{mg} / \mathrm{kg})$. However, the anxiolytic-like effects of EMA $(200 \mathrm{mg} / \mathrm{kg})$ were blocked by thioperamide $(10 \mathrm{mg} /$ $\mathrm{kg}$ ), which is a $\mathrm{H}_{3}$ receptor antagonist.

Effect of EMA on the Locomotor Activity Test and Horizontal Wire Test False-positive results might be argued in these behavioural tasks with drugs that stimulate locomotion. ${ }^{19)}$ However, as summarised in Table 1, no alterations in locomotor activity or rearing frequencies were observed in mice administered EMA with the doses of 50, 100, 200 or $400 \mathrm{mg} / \mathrm{kg}$ in the open-field test compared with vehicle-treated animals.

Moreover, at $5 \mathrm{mg} / \mathrm{kg}$, diazepam significantly decreased the percentage of mice grasping the wire (Fig. 4). In contrast, EMA $(50,100,200$ and $400 \mathrm{mg} / \mathrm{kg})$ did not decrease the percentage of mice grasping the wire compared with vehicletreated control group, indicating a lack of myorelaxation at these doses.

Effect of EMA on HDC mRNA Expression Levels in the Amygdala Region To investigate the effects of EMA on the 


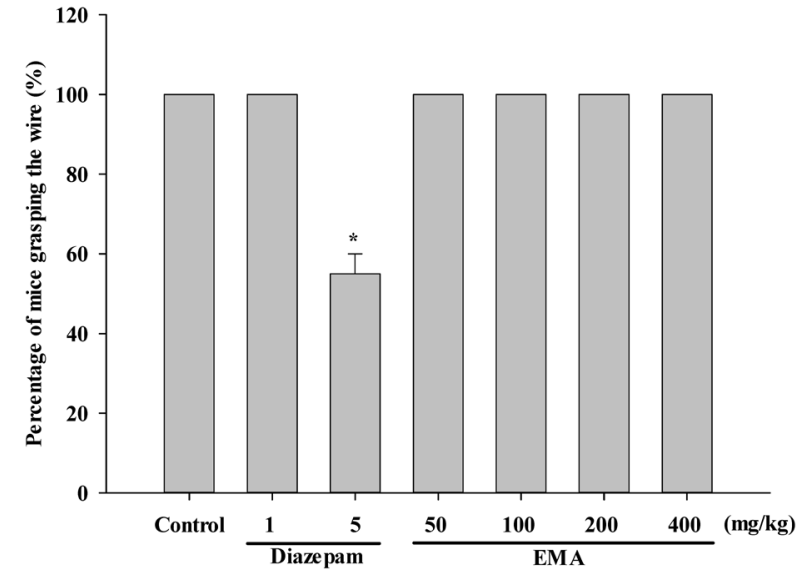

Fig. 4. Performance of Mice in the Horizontal Wire Test $1 \mathrm{~h}$ after Oral Administration of Control, Diazepam (1 and $5 \mathrm{mg} / \mathrm{kg}$ ), or $M$. alba Leaves (EMA)

Data represent percentage of mice grasping the wire after administration of EMA. Each bar represents the mean \pm S.E.M. of 10 mice. $p$ values for group comparisons were obtained by one way ANOVA followed by Student-Newman-Keuls test $(* p<0.05$ versus the vehicle-treated control).

Table 1. Locomotor Activity Effects of the Methanolic Extract of the Leaves of Morus alba L. (EMA) on Open Field Test in Mice

\begin{tabular}{ccc}
\hline \hline & $\begin{array}{c}\text { Total distance moved } \\
(\mathrm{cm} / 5 \mathrm{~min})\end{array}$ & $\begin{array}{c}\text { Frequency of rearing } \\
(\text { No. })\end{array}$ \\
\hline Control & $2283.8 \pm 171.0$ & $99.1 \pm 4.2$ \\
EMA (mg/kg) & & \\
50 & $2202.3 \pm 67.1$ & $105.4 \pm 4.8$ \\
100 & $2289.7 \pm 111.5$ & $106.3 \pm 3.2$ \\
200 & $2376.1 \pm 145.9$ & $99.5 \pm 3.9$ \\
400 & $2065.1 \pm 87.8$ & $100.0 \pm 5.2$ \\
\hline
\end{tabular}

Spontaneous locomotor behaviour was measured in the open-field test for $5 \mathrm{~min}$ as described in Materials and Methods. Animals were orally treated with EMA (50, 100 , 200 or $400 \mathrm{mg} / \mathrm{kg}$ ) $1 \mathrm{~h}$ before the test. Control animals were treated with the same volume of vehicle. Data are expressed as the means \pm S.E.M. ( $n=9-10 /$ group).

release of HDC which is a molecule crucial for anxiolytic-like behavior, we conducted RT-PCR analyses after the administration of EMA. Results from RT-PCT also revealed that the amygdalal HDC mRNA expression levels in EMA (200 mg/ $\mathrm{kg}$ )-treated group were significantly higher than those in the vehicle-treated controls ( $p<0.05$, Fig. 5).

\section{DISCUSSION}

In this study, the effects of EMA were examined in animal models of anxiety using the elevated plus-maze, hole-board test, horizontal wire test and locomotor activity, which are classic models for screening anxiety and myorelaxant activity. The main findings of this study were that EMA treatment significantly increased the time spent in the open arms and the frequency of open arm entries and that these effects were antagonised by thioperamide, suggesting the involvement of the central histaminergic neurons in the central nervous system (CNS). In the hole-board test, the treatment with EMA significantly increased the number of head-dips compared with the vehicle-treated controls. Moreover, no changes in locomotor activity or myorelaxant effects were observed. Therefore, we suggest that EMA has an anxiolytic-like effect due to hista-
A.

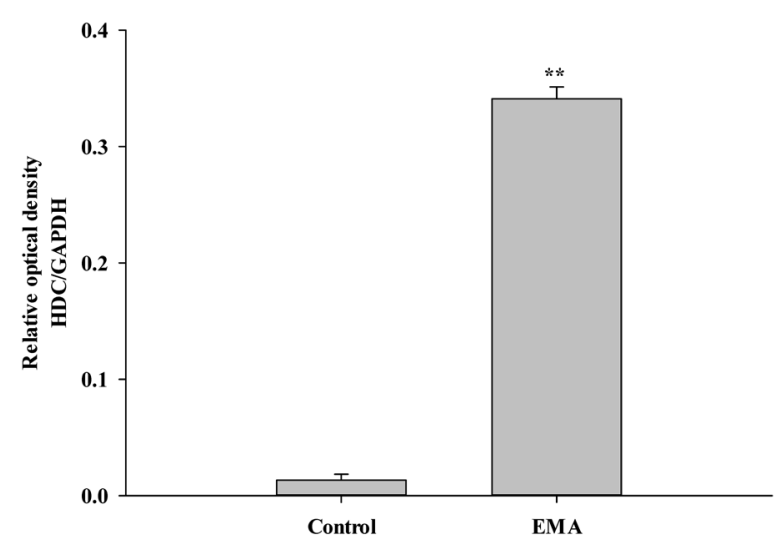

B.

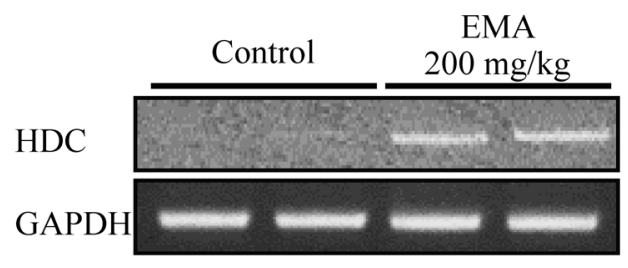

Fig. 5. Effects of Administration of Methanolic Extract of the Leaves of Morus alba L. (EMA) on Histidine Decarboxylase (HDC) Expression in the Amygdala of Mice

(A) Quantitative analysis of the expression of HDC mRNA and (B) RT-PCR for HDC mRNA and its quantitative analysis in the amygdala $1 \mathrm{~h}$ after EMA (200 mg/ $\mathrm{kg}$, p.o.) administration. Control animals were treated with the same volume of saline. Values are expressed as means \pm S.E.M. ( $n=4 /$ group). ${ }^{*} p<0.05$, compared with the control group.

mine receptor activation and that it has no adverse effects, such as myorelaxant effects.

Histaminergic neurons, which originate from the tuberomammillary nucleus in the posterior hypothalamus, project diffusely throughout the CNS and have implicated in the regulation of many functions, including emotion, sleep/wake, thermoregulation, memory, and other homeostatic processes. ${ }^{20,21)}$ Recently, it has been reported that the activation of the histamine $\mathrm{H}_{1}$ receptor has anxiogenic effects. Additionally, a histamine releasing agent, compound 48/80, exhibits angiogenic properties. ${ }^{22,23)}$ Those previous reports suggest that the histaminergic system plays an important role in the anxiety behaviour. Moreover, we hypothesised that EMA might exhibit its effects through affecting through altering histaminergic neurotransmission because it affected various hypothalamic functions including reduced nicotinamide adenine dinucleotide phosphate (NADPH) diaphorase and Neuropeptide Y immunoreactivities. We investigated this hypothesis whether the anxiolytic-like properties of EMA would be antagonised by thioperamide, which is a histamine $\mathrm{H}_{3}$ receptor antagonist.

In the present study, the administration of EMA increased the percentages of entries into open arms and time spent in the open arms. Although Yadav et al. ${ }^{8)}$ demonstrated that intraperitoneal administration with methanolic extract of $M$. alba L. induced a motor depressant effect, indicating a significant skeletal muscle relaxant and sedative effect, based on the results of their behavioural experiments, EMA did not alter 
spontaneous behaviour and exerted no significant myorelaxant effect at the chosen dosage regimen as measured using the horizontal wire test. Total distances of movement on the EPM were not changed by EMA treatment versus the vehicle-treated control group (data not shown). These observations indicate that the anxiolytic effect of EMA is not simply the result of either a general stimulation of locomotor activity or exploratory behaviour consequent to exposure to a novel environment. Interestingly, the increase of the percentage of entries into open arms by the EMA treatment was significantly decreased in the vehicle-treated group by administration of thioperamide. Moreover, the percentage of time spent in the open arms showed a similar pattern. The $\mathrm{H}_{3}$ receptor was initially described as a presynaptically located autoreceptor regulating histamine synthesis and release of histamine from neuronal synaptic vesicles. ${ }^{24)}$ Thioperamide is a selective antagonist of the $\mathrm{H}_{3}$ receptor and increases histamine release by blocking presynaptic $\mathrm{H}_{3}$ autoreceptor. ${ }^{25}$ ) Therefore, the antagonistic effects of thioperamide on the EMA in the EPM suggest that EMA has an antagonistic activity in the histaminergic synaptic cleft. However, we could not identify the exact properties of EMA - namely, whether EMA acts as a $\mathrm{H}_{1}$ receptor antagonist, a $\mathrm{H}_{2}$ receptor antagonist or a $\mathrm{H}_{3}$ receptor agonist. Each of the three is likely to inhibit the effects of thioperamide in the EPM. If EMA exhibits its effects through as a $\mathrm{H}_{3}$ receptor agonist, those effects in the EPM might be potentiated by the treatment of $R$ - $\alpha$-methylhistidine, which is a specific agonist of the $\mathrm{H}_{3}$ receptor. However, we did not observe any changes of the percentage of entries into open arms or the percentage of spent time in open arms with $R$ - $\alpha$-methylhistamine (data not shown). Yuzurihara et $a l^{9)}$ reported that the activation of the $\mathrm{H}_{2}$ receptor inhibits the anxiety in mice. These previous observations and our results mean that EMA exhibits its anxiolytic-like behaviour via blockade of the $\mathrm{H}_{1}$ receptor. However, further research is needed to clarify these issues.

Several lines of evidence indicate that the central histaminergic activity is regulated by serotonergic or GABAergic neurotransmission with regard to anxiety-like behaviours. Buspirone, which is a $5-\mathrm{HT}_{1 \mathrm{~A}}$ receptor agonist, has been used as an anxiolytic drug and has been found to decrease the turnover rate of brain histamine in mice and rats. ${ }^{26)}$ The effects of histamine turnover rate and extracellular histamine level were also affected by the administration of diazepam, which is a GABA $_{\mathrm{A}}$ agonist. ${ }^{6,7)}$ These previous observations suggest that the anxiolytic properties of EMA might be associated with the $5-\mathrm{HT}_{1 \mathrm{~A}}$ receptor or $\mathrm{GABA}_{\mathrm{A}}$ receptor. We tested these possibilities using flumazenil, which is a $\mathrm{GABA}_{\mathrm{A}}$ antagonist, and WAY-100635, a 5- $\mathrm{HT}_{1 \mathrm{~A}}$ receptor antagonist. Neither flumazenil nor WAY-100635 showed any changes in the percentage of entries into open arms and the percentage of time spent in the open arms, as shown in the previous reports. ${ }^{14,27)}$ With the administration of flumazenil, the increases of the percentages of entries into open arms and time spent in the open arms were not changed compared with those of EMA treatment. Moreover, the similar results were also obtained with the treatment of WAY-100635. Taken together, these results suggest that the anxiolytic-like effects of EMA are selective and are mediated through the $\mathrm{H}_{1}$ receptor, and not the $5-\mathrm{HT}_{1 \mathrm{~A}}$ or the $\mathrm{GABA}_{\mathrm{A}}$ receptor.

HDC is the enzyme converts L-histidine to histamine. ${ }^{28)}$ Meguro et $a .^{29)}$ reported that HDC activity is a good marker for the central histaminergic neuron system. In previous report, HDC knockout animals exhibit altered mast cell development and increased bone formation ${ }^{30)}$ the irreversible inhibitor of HDC, $\alpha$-fluoromethyl-[S]-histidine, which produces histamine loss in a tissue-dependent fashion, ${ }^{31)}$ reduced locomotor activity in the open-field and an avoidance learning test. ${ }^{32)}$ In addition, HDC knockout mice also showed reduced exploratory behavior in the open-field, reduced locomotor activity in the home cage in the dark, increased measures of anxiety on the elevated plus-maze, impairments in long-term object recognition memory, and enhanced motor coordination on the rotorod. ${ }^{32-36)}$ In the present study, the increase in expression levels of HDC mRNA in the amygdala region after EMA administration suggests that the anxiolytic-like activity are dependent on HDC expression in the amygdala.

In the present study, the exact reasons why the higher dose of EMA $(400 \mathrm{mg} / \mathrm{kg})$ was less effective than that of lower doses $(200 \mathrm{mg} / \mathrm{kg})$ are unclear. However, it is possible that these phenomena were observed because any neurotransmitter autoreceptor of any neurotransmitters. Similar bell-shaped dose-response curves have been reported after psychiatric treatment for drugs such as buspirone, cannabidiol and etc.other. ${ }^{37,38)}$ Although the reason for these bell-shaped curves in the EPM is still obscure, the same bell-shaped trends have been observed previously in the reports on agmatine ${ }^{39,40)}$ and GMP ${ }^{41)}$ which are endogenous modulatory compounds that produce their anxiolytic-like effects. Most of the anxiolytic effects are due to the amount of neurotransmitters in the synaptic cleft. Although we did not measure the neurotransmitters contents in the synaptic cleft, we assumed that EMA could also influence on neurotransmitter concentration in the synaptic cleft. Therefore, we consider that the bell-shaped dose-dependent curves for EMA in the present studies resulted from its influences on neurotransmitters and receptors. Further studies are needed to clarify these issues.

Until now, it has not been clear which constituent of EMA exerts its anxiolytic-like effects. Several reports exist on compounds isolated from the leaves of $M$. alba including flavone derivatives, unsaturated acid, and lignan glycoside. ${ }^{42)}$ Of these constituents, quercetin, which is a flavonoid compound, is known to be contained high amounts. ${ }^{43}$ Moreover, quercetin is reported to have antagonistic activity to the histamine $\mathrm{H}_{2}$ receptor at a high dosage $(200 \mathrm{mg} / \mathrm{kg}) .{ }^{44)}$ If quercetin is the main contributory compound in this anxiolytic-like behaviour, EMA should have a high concentration of quercetin. Our unpublished data also showed that quercetin exhibited its behavioural properties via the $\mathrm{GABA}_{\mathrm{A}-\rho}$ receptor, rather than histaminergic receptor (data not shown). Although this is speculative, the main contributory compounds might not be quercetin but may be other species. At present, we do not conclude that the histaminergic nervous system is the only system involved in the anxiolytic-like effects of EMA. We are currently investigating the major component(s) of EMA involved in the anxiolytic-like effect and the exact receptor systems associated with the effects.

Although benzodiazepines remain the mainstay of drug treatment in anxiety disorders, safer and more specific anxiolytics are needed because those compounds have prominent side-effects, such as sedation, myorelaxation, ataxia, amnesia, and pharmacological dependence. ${ }^{45}$ Natural anxiolytic agents are featured in such research because herbs have been used 
to treat psychiatric disorders and generally have fewer harmful effects. ${ }^{46)}$ The potential clinical benefits of some herbal remedies commonly used in psychiatric practice have been addressed in earlier reviews. ${ }^{47-51)}$ Until now, we have investigated the anxiolytic agents from the herbal materials. Because the leaves of $M$. alba have been consumed for generations in Eastern Asia, it is unlikely that the leaves have side effects that are severe enough to prevent their pharmacological activities alone or in combination with other agents.

In summary, the present results demonstrate that the methanolic extract of $M$. alba leaves exerts an anxiolytic-like effect and that histaminergic neurotransmission is involved in that effect. Although the underlying mode of action remains to be elucidated and the findings of herb effects may not be clinically useful outcomes in patients or in humans, the findings of this study may be important in confirming the medicinal action of the leaves of M. alba.

Acknowledgment This research was supported by Research Center for Biochemical Resources of Oriental Medicine (B0009008).

\section{REFERENCES}

1) Asano N, Yamashita $T$, Yasuda $K$, Ikeda $K$, Kizu H, Kameda $Y$, Kato A, Nash RJ, Lee HS, Ryu KS. Polyhydroxylated alkaloids isolated from mulberry trees (Morus alba L.) and silkworms (Bombyx mori L.). J. Agric. Food Chem., 49, 4208-4213 (2001).

2) Hwang KH, Kim YK. Promoting effect and recovery activity from physical stress of the fruit of Morus alba. Biofactors, 21, 267-271 (2004).

3) Chen F, Nakashima N, Kimura I, Kimura M. Hypoglycemic activity and mechanisms of extracts from mulberry leaves (Folium mori) and Cortex mori radicis in streptozotocin-induced diabetic mice. Yakugaku Zasshi, 115, 476-482 (1995).

4) Jang MH, Kim H, Shin MC, Lim BV, Lee TH, Jung SB, Kim CJ, Kim EH. Administration of Folium mori extract decreases nitric oxide synthase expression in the hypothalamus of streptozotocininduced diabetic rats. Jpn. J. Pharmacol., 90, 189-192 (2002).

5) Ericson H, Watanabe T, Köhler C. Morphological analysis of the tuberomammillary nucleus in the rat brain: delineation of subgroups with antibody against L-histidine decarboxylase as a marker. $J$. Comp. Neurol., 263, 1-24 (1987).

6) Oishi R, Nishibori M, Itoh Y, Saeki K. Diazepam-induced decrease in histamine turnover in mouse brain. Eur. J. Pharmacol., 124, 337-342 (1986)

7) Chikai T, Oishi R, Saeki K. Microdialysis study of the effects of sedative drugs on extracellular histamine in the striatum of freely moving rats. J. Pharmacol. Exp. Ther., 266, 1277-1281 (1993).

8) Yadav AV, Kawale LA, Nade VS. Effect of Morus alba L. (mulberry) leaves on anxiety in mice. Indian J. Pharmacol., 40, 32-36 (2008).

9) Yuzurihara M, Ikarashi Y, Ishige A, Sasaki H, Kuribara H, Maruyama Y. Effects of drugs acting as histamine releasers or histamine receptor blockers on an experimental anxiety model in mice. Pharmacol. Biochem. Behav., 67, 145-150 (2000).

10) Lister RG. The use of a plus-maze to measure anxiety in the mouse. Psychopharmacology (Berl.), 92, 180-185 (1987).

11) Pellow S, File SE. Anxiolytic and anxiogenic drug effects on exploratory activity in an elevated plus-maze: a novel test of anxiety in the rat. Pharmacol. Biochem. Behav., 24, 525-529 (1986).

12) Commission CP. Pharmacopoeia of the People's Republic of China. Chemical Industry Press, Beijing (2005).

13) Jung JW, Cho JH, Ahn NY, Oh HR, Kim SY, Jang CG,
Ryu JH. Effect of chronic Albizzia julibrissin treatment on 5-hydroxytryptamine ${ }_{1 \mathrm{~A}}$ receptors in rat brain. Pharmacol. Biochem. Behav., 81, 205-210 (2005).

14) Jung JW, Yoon BH, Oh HR, Ahn JH, Kim SY, Park SY, Ryu JH. Anxiolytic-like effects of Gastrodia elata and its phenolic constituents in mice. Biol. Pharm. Bull., 29, 261-265 (2006).

15) Pérez-Garcia C, Morales L, Cano MV, Sancho I, Alguacil LF. Effects of histamine $\mathrm{H}_{3}$ receptor ligands in experimental models of anxiety and depression. Psychopharmacology (Berl.), 142, 215-220 (1999).

16) Takeda H, Tsuji M, Matsumiya T. Changes in head-dipping behavior in the hole-board test reflect the anxiogenic and/or anxiolytic state in mice. Eur. J. Pharmacol., 350, 21-29 (1998).

17) Bonetti EP, Pieri L, Cumin R, Schaffner R, Pieri M, Gamzu ER, Müller RK, Haefely W. Benzodiazepine antagonist Ro 15-1788: neurological and behavioral effects. Psychopharmacology (Berl.), 78, 8-18 (1982).

18) Fabene PF, Mariotti R, Navarro Mora G, Chakir A, Zancanaro C. Forced mild physical training-induced effects on cognitive and locomotory behavior in old mice. J. Nutr. Health Aging, 12, 388-390 (2008).

19) Bourin M, Fiocco AJ, Clenet F. How valuable are animal models in defining antidepressant activity? Hum. Psychopharmacol., 16, 9-21 (2001).

20) Markov D, Goldman M. Normal sleep and circadian rhythms: neurobiologic mechanisms underlying sleep and wakefulness. Psychiatr. Clin. North Am., 29, 841-853, abstract, vii (2006).

21) Sakata T, Yoshimatsu H, Kurokawa M. Thermoregulation modulated by hypothalamic histamine in rats. Inflamm. Res., 46 (Suppl. 1), 35-36 (1997).

22) Malmberg-Aiello P, Ipponi A, Bartolini A, Schunack W. Mouse light/dark box test reveals anxiogenic-like effects by activation of histamine H1 receptors. Pharmacol. Biochem. Behav., 71, 313-318 (2002).

23) Rostami P, Hajizadeh-Moghaddam A, Zarrindast MR. The effects of histaminergic agents in the ventral hippocampus of rats in the plus-maze test of anxiety-like behaviours. Physiol. Behav., 87, 891-896 (2006).

24) Arrang JM, Garbarg M, Schwartz JC. Auto-inhibition of brain histamine release mediated by a novel class $\left(\mathrm{H}_{3}\right)$ of histamine receptor. Nature, 302, 832-837 (1983).

25) Vohora D, Pal SN, Pillai KK. Thioperamide, a selective histamine $\mathrm{H}_{3}$ receptor antagonist, protects against PTZ-induced seizures in mice. Life Sci., 66, PL297-PL301 (2000).

26) Oishi R, Itoh Y, Saeki K. Inhibition of histamine turnover by $8-\mathrm{OH}-$ DPAT, buspirone and 5-hydroxytryptophan in the mouse and rat brain. Naunyn Schmiedebergs Arch. Pharmacol., 345, 495-499 (1992).

27) Atack J, Hallett DJ, Tye S, Wafford KA, Ryan C, Sanabria-Bohorquez S, Eng WS, Gibson RE, Burns HD, Dawson GR, Carling RW, Street LJ, Pike A, De Lepeleire I, Van Laere K, Bormans G, de Hoon JN, Van Hecken A, McKernan RM, Murphy MG, Hargreaves RJ. Preclinical and clinical pharmacology of TPA023B, a GABA receptor a2/a3 subtype-selective partial agonis. J. Psychopharmacol., 25, 329-344 (2010).

28) Ohtsu H, Tanaka S, Terui T, Hori Y, Makabe-Kobayashi Y, Pejler G, Tchougounova E, Hellman L, Gertsenstein M, Hirasawa N, Sakurai E, Buzas E, Kovacs P, Csaba G, Kittel A, Okada M, Hara M, Mar L, Numayama-Tsuruta K, Ishigaki-Suzuki S, Ohuchi K, Ichikawa A, Falus A, Watanabe T, Nagy A. Mice lacking histidine decarboxylase exhibit abnormal mast cells. FEBS Lett., 502, 53-56 (2001).

29) Meguro K, Yanai K, Sakai N, Sakurai E, Maeyama K, Sasaki H, Watanabe T. Effects of thioperamide, a histamine $\mathrm{H}_{3}$ antagonist, on the step-through passive avoidance response and histidine decarboxylase activity in senescence-accelerated mice. Pharmacol. 
Biochem. Behav., 50, 321-325 (1995).

30) Ohtsu H, Watanabe T. New functions of histamine found in histidine decarboxylase gene knockout mice. Biochem. Biophys. Res. Commun., 305, 443-447 (2003).

31) Watanabe T, Yamatodani A, Maeyama K, Wada H. Pharmacology of alpha-fluoromethylhistidine, a specific inhibitor of histidine decarboxylase. Trends Pharmacol. Sci., 11, 363-367 (1990).

32) Cacabelos R, Alvarez XA. Histidine decarboxylase inhibition induced by alpha-fluoromethylhistidine provokes learning-related hypokinetic activity. Agents Actions, 33, 131-134 (1991).

33) Abe H, Honma S, Ohtsu H, Honma K. Circadian rhythms in behavior and clock gene expressions in the brain of mice lacking histidine decarboxylase. Brain Res. Mol. Brain Res., 124, 178-187 (2004).

34) Dere E, De Souza-Silva MA, Spieler RE, Lin JS, Ohtsu H, Haas HL, Huston JP. Changes in motoric, exploratory and emotional behaviours and neuronal acetylcholine content and 5-HT turnover in histidine decarboxylase-KO mice. Eur. J. Neurosci., 20, 1051-1058 (2004).

35) Matsue H, Rothberg KG, Takashima A, Kamen BA, Anderson RG, Lacey SW. Folate receptor allows cells to grow in low concentrations of 5-methyltetrahydrofolate. Proc. Natl. Acad. Sci. U.S.A., 89, 6006-6009 (1992).

36) Toyota H, Dugovic C, Koehl M, Laposky AD, Weber C, Ngo K, Wu Y, Lee DH, Yanai K, Sakurai E, Watanabe T, Liu C, Chen J, Barbier AJ, Turek FW, Fung-Leung WP, Lovenberg TW. Behavioral characterization of mice lacking histamine $\mathrm{H}_{3}$ receptors. Mol. Pharmacol., 62, 389-397 (2002).

37) Guimarães FS, Chiaretti TM, Graeff FG, Zuardi AW. Antianxiety effect of cannabidiol in the elevated plus-maze. Psychopharmacology (Berl.), 100, 558-559 (1990).

38) Vaidya AH, Rosenthal DI, Lang W, Crooke JJ, Benjamin D, Ilyin SE, Reitz AB. Oral buspirone causes a shift in the dose-response curve between the elevated-plus maze and Vogel conflict tests in Long-Evans rats: relation of brain levels of buspirone and 1-PP to anxiolytic action. Methods Find. Exp. Clin. Pharmacol., 27, 245255 (2005).

39) Li YF, Gong ZH, Cao JB, Wang HL, Luo ZP, Li J. Antidepressant- like effect of agmatine and its possible mechanism. Eur. J. Pharmacol., 469, 81-88 (2003).

40) Zomkowski AD, Hammes L, Lin J, Calixto JB, Santos AR, Rodrigues AL. Agmatine produces antidepressant-like effects in two models of depression in mice. Neuroreport, 13, 387-391 (2002).

41) Eckeli AL, Dach F, Rodrigues AL. Acute treatments with GMP produce antidepressant-like effects in mice. Neuroreport, 11, 18391843 (2000).

42) Li WL, Zheng HC, Bukuru J, De Kimpe N. Natural medicines used in the traditional Chinese medical system for therapy of diabetes mellitus. J. Ethnopharmacol., 92, 1-21 (2004).

43) Hirayama C, Ono H, Tamura Y, Konno K, Nakamura M. Regioselective formation of quercetin 5-O-glucoside from orally administered quercetin in the silkworm, Bombyx mori. Phytochemistry, 69, 1141-1149 (2008).

44) Kahraman A, Erkasap N, Koken T, Serteser M, Aktepe F, Erkasap $\mathrm{S}$. The antioxidative and antihistaminic properties of quercetin in ethanol-induced gastric lesions. Toxicology, 183, 133-142 (2003).

$45)$ Lader M, Morton S. Benzodiazepine problems. Br. J. Addict., 86, 823-828 (1991).

46) Carlini EA. Plants and the central nervous system. Pharmacol. Biochem. Behav., 75, 501-512 (2003).

47) Beaubrun G, Gray GE. A review of herbal medicines for psychiatric disorders. Psychiatr. Serv., 51, 1130-1134 (2000).

48) Desai AK, Grossberg GT. Herbas and botanicals in geriatric psychiatry. Am. J. Geriat. Psychiatry, 11, 498-506 (2003).

49) Fugh-Berman A, Cott JM. Dietary supplements and natural products as psychotherapeutic agents. Psychosom. Med., 61, 712-728 (1999).

50) Lake J. Psychotropic medications from natural products: a review of promising research and recommendations. Altern. Ther. Health Med., 6, 36-52 (2000).

51) Linde K, ter Riet G, Hondras M, Vickers A, Saller R, Melchart D. Systematic reviews of herbal medicines-an annotated bibliography. Forschende Komplementarmedizin und klassische Naturheilkunde (Research in complementary and natural classical medicine), 10 (Suppl. 1), 17-27 (2003). 